\title{
A kiégés elöfordulása szociális munkások körében
}

\section{Mák Kornél dr. ${ }^{1}$ - Fejes Éva dr. ${ }^{1,2}$ - Pohl Marietta dr. ${ }^{1}$. Kolonics Gábor dr. ${ }^{1}$ Tóth Gábor dr. ${ }^{3}$. Zádori Iván ${ }^{4}$. Nemeskéri Zsolt dr. ${ }^{4}$ Hesszenberger Dávid dr. ${ }^{5}$. Fehér Gergely dr. ${ }^{1,6}$. Tibold Antal dr. ${ }^{1}$}

\author{
${ }^{1}$ Pécsi Tudományegyetem, Általános Orvostudományi Kar, Klinikai Központ, \\ Foglalkozás-egészségügyi és Munkahigiénés Központ, Pécs \\ ${ }^{2}$ Komlói Egészségcentrum, Bányászati Utókezelő és Éjjeli Szanatórium Egészségügyi Központ, Komló \\ ${ }^{3}$ Bajai Szent Rókus Kórház, Baja \\ ${ }^{4}$ Pécsi Tudományegyetem, Kultúratudományi, Pedagógusképző és Vidékfejlesztési Kar, \\ Kultúra- és Társadalomtudományi Intézet, Pécs \\ ${ }^{5}$ Pécsi Tudományegyetem, Általános Orvostudományi Kar, Klinikai Központ, \\ Laboratóriumi Medicina Intézet, Pécs \\ ${ }^{6}$ EÜ-MED Kft., Neurológiai Szakrendelés, Komló
}

\begin{abstract}
Bevezetés: Napjaink egyik legszélesebb körben emlegetett jelensége a kiégés (burnout), mely a leggyakrabban a segítő szakmákban dolgozókat érinti.

Célkitüzés: Munkánk célja a kiégés jelenségének komplex vizsgálata szociális munkások körében.

Módszerek: A demográfiai adatok felvétele mellett a kiégés vizsgálatához a Maslach Burnout Inventory (MBI) kérdőívet használtuk, a kognitív/viselkedésbeli hibákat, diszfunkcionális elvárásokat pedig a Diszfunkcionális Attitűd Skála (DAS) segítségével térképeztük fel. A hangulatzavar kimutatásához a Beck Depresszió Kérdőív rövidített változatát alkalmaztuk, továbbá az Erőfeszítés-Jutalom Egyensúlytalanság Kérdőív és a Társas Támogatás Kérdőív is kitöltésre került.

Eredmények: Összesen 300 fő töltötte ki a kérdőívet: 106 férfi, 194 nő. A munkavállalók döntően a fiatal/középkorú korcsoporthoz tartoznak, a 26-45 év közöttiek aránya 52,2\%. Az átlagos kiégési pontszám 53,9 (SD = 18,7) volt, melyből 105 fó $(35,1 \%)$ alacsony, 182 fó közepes $(60,6 \%)$ és 13 fó $(4,3 \%)$ súlyos kiégéssel érintett. A multivariációs analízis során a női nem (OR: 5,857), az életkor (OR: 4,126), a munkában eltöltött évek (OR: 2,721), a sokgyermekes család (OR: 2,861) és a társas támogatás hiánya (OR: 2,81) bizonyultak a kiégés független rizikótényezőinek ( $p<0,05$ minden esetben). A depresszió és a kiégés $(\mathrm{p}<0,001)$, valamint a diszfunkcionális attitűdök és a kiégés között pozitív kapcsolat igazolódott (korrelációs együttható $=0,316 ; \mathrm{p}<0,001$ ).

Következtetés: Eredményeink alapján a szociális munkások jelentős része közepes fokú kiégésben, 5\%-uk pedig súlyos fokú kiégésben szenved. A kiégésnek vannak befolyásolható (munkahelyi attitűdök, társas támogatás) és nem befolyásolható (életkor, nem, család) tényezői, melyeket az esetleges prevenciós, illetve intervenciós beavatkozások során figyelembe kell venni.

Orv Hetil. 2020; 161(44): 1884-1890.
\end{abstract}

Kulcsszavak: kiégés, depresszió, diszfunkcionális attitűdök, szociális munkás

\section{Burnout among social workers}

Introduction: Burnout is increasingly prevalent mainly involving employees working in the social sphere. Objective: The aim of our study was to examine the complexity of burnout among social workers.

Methods: Baseline demographic data were recorded. Burnout was assessed by the Maslach Burnout Inventory (MBI), and the intensities of dysfunctional attitudes were also studied. Depression was detected by the abbreviated version of the Beck Depression Questionnaire, furthermore social supports and effort-reward imbalance were also examined. Results: Overall 300 employees participated in our study. Age group distribution was young/middle-aged access, the vast majority of the workers was between 25 and 45 years. The mean burnout scale was $53.9(\mathrm{SD}=18.7), 105$ workers had mild $(35.1 \%), 182$ moderate $(60.6 \%)$ and 13 severe $(4.3 \%)$ burnout. In a multivariate analysis, the female gender (OR: 5.857$)$, the age (OR: 4.126), the years spent with working (OR: 2.721$)$, the number of children $(>3)$ 
(OR: 2.861) and the lack of social support (OR: 2.81) were independently associated with burnout $(\mathrm{p}<0.05$ in all cases). There was a significant association among burnout, depression and dysfunctional attitudes.

Conclusion: The vast majority of our social workers suffered from moderate and a small, but a significant proportion from severe burnout. Our work draws attention to the modifiable and unmodifiable risk factors of burnout in this population, which may help in the development of preventive strategies.

Keywords: burnout, depression, dysfunctional attitudes, social worker

Mák K, Fejes É, Pohl M, Kolonics G, Tóth G, Zádori I, Nemeskéri Zs, Hesszenberger D, Fehér G, Tibold A. [Burnout among social workers]. Orv Hetil. 2020; 161(44): 1884-1890.

(Beérkezett: 2020. március 18.; elfogadva: 2020. május 21.)

\section{Rövidítések}

ÁGOTA = Állami Gondoskodásban Élő és Veszélyeztetett Fiatalok Támogatásáért Alapítvány; DAS = Diszfunkcionális Attitüd Skála; MBI = (Maslach Burnout Inventory) Maslach Kiégés Leltár; $\mathrm{OR}=$ (odds ratio) esélyhányados; PTE $=$ Pécsi Tudományegyetem; SD = standard deviáció; $\mathrm{WHO}=($ World Health Organization) Egészségügyi Világszervezet

Napjaink egyik legszélesebb körben emlegetett jelensége a kiégés (burnout), mely paradox módon talán a legnagyobb mértékben az egészségügyi személyzetet érinti. Gyakorisága okán korunk járványának is nevezik (a cukorbetegség mellett) [1]. A túlterhelés/teljesítménykényszer (akár belső késztetés, akár külső tényezők - munkaerőhiány - okán), a fokozott stressz, a munkafüggőség és - mánia a szindróma kialakulásának legfontosabb tényezói, különösen azokban az esetekben, amikor a munkavégzés hosszú időn át emberekre irányul, hoszszan tartó koncentrálást és érzelmi bevonódást, aktív beavatkozást követel, miközben a gyors látványos eredmények, pozitív visszajelzések viszonylag ritkák (ebbe a csoportba tartoznak az egészségügyi dolgozók, a pedagógusok, a szociális munkások, a lelkészek, a terapeuták stb.) [2].

A kiégéssel foglalkozó nemzetközi és hazai szakirodalom döntően az egészségügyi személyzetre fókuszál. Hazai adatok alapján az egészségügyben dolgozók mintegy fele valamilyen fokú kiégésben szenved, mely a szakdolgozókat nagyobb arányban érinti az orvosokhoz képest [3-5].

Noha besorolása szerint a kiégés foglalkozási megbetegedésnek számít, a pszichés/érzelmi kimerültség és munkaképesség-csökkenés mellett szignifikáns összefüggés látszik ábrázolódni a cukor- és cardiovascularis betegségekkel, a különböző fájdalomszindrómákkal, légzésszervi és gastrointestinalis megbetegedésekkel, továbbá a fiatalkori (<45 év) halálozás fellépésével, ami a kórkép klasszifikációjának újragondolását teszi szükségessé [6].

A szociális munkások olyan alapvető ellátási helyeken dolgoznak, mint például a családsegítő szolgálatok, gyermekvédelem, idősotthonok, pszichiátriai rehabilitáció. Munkájuk természetéból eredően fokozottan veszélyeztetett csoportnak számítanak a munkahelyi kiégés tekintetében, hiszen napi munkavégzésükhöz elengedhetetlen az empátia (beleérző képesség), a páciens érzelmi és egészségügyi állapotának maximális figyelembevétele, mely gyakran bizonyos fokú érzelmi kapcsolat kialakulásával is jár [7]. A kiégés potenciálisan hátrányosan befolyásolja a munkavégzés hatékonyságát, az ellátottak elégedetlenségéhez vezetve, rontva a munkahelyi kapcsolatokat, tágabb értelemben véve súlyos társadalmi következményeket okozva $[7,8]$.

A képet súlyosbítja, hogy napjainkra a dolgozók megtartása és a humánerőforrás fejlesztése az ellátás biztosításához nélkülözhetetlenné vált a munkakörök túlnyomó többségében (ez különösen igaz az egészségügyiszociális és az építőipari ágazatokra), hiszen jelentősen megnőtt a pályaelhagyók és a külföldön munkát vállalók száma. A szociális szférában dolgozók megtartása, egészségük megőrzése kiemelt szerephez jut, hiszen a túlterhelt személyzet kiégésével a munkabírásuk és teljesítőképességük, ebből adódóan az általuk nyújtott szolgáltatás minősége is csökken, ami társadalmunk legkiszolgáltatottabb helyzetben lévő tagjainak életére nézve is komoly hatással van.

Mindazonáltal hazánkban összetett állapotfelmérés nem áll rendelkezésre a szociális szférában dolgozók kiégéséről. Munkánk célja a kiégés hátterének komplex vizsgálata szociális munkások körében.

\section{Módszerek}

A strukturált kérdőívekre alapozott keresztmetszeti vizsgálat a 2018. április 1. és 2019. március 31. közötti időszakban zajlott Magyarországon, Kecskemét városában (a PTE/96773-2/2018. számú etikai engedély alapján). A vizsgálatba bevont dolgozók az Állami Gondoskodásban Élő és Veszélyeztetett Fiatalok Támogatásáért Alapítvány (ÁGOTA) munkavállalói. Az eljárás egyszerü, nem véletlenszerü mintavétel volt. 
Beválasztási kritérium volt, hogy a válaszadók az adott intézményeknél a kutatás időpontjában közalkalmazotti, alkalmazotti, megbízási jogviszonyban vagy személyes közremúködőként foglalkoztatottak legyenek. Nem kerültek be a mintánkba azok a dolgozók, akik tartós távolléten voltak a vizsgálat lebonyolításának időpontjában.

A vizsgálat során tekintetbe vett demográfiai adatok az alábbiak voltak: életkor, nem, családi állapot, a gyermekek száma, iskolai végzettség, munkakör, a munkával eltöltött évek száma, munkarend, a jogviszony típusa, másodállás vállalása.

A kiégés vizsgálatához a Maslach Burnout Inventory (MBI) kérdőívet használtuk, mely az érzelmi kimerülést, a deperszonalizációt és a személyes teljesítménycsökkenést vizsgálja egy rövid, 22 állításból álló, könnyen kitölthető és egyszerüen értékelhető teszt keretében $[9,10]$.

A kognitív/viselkedésbeli hibákat, a diszfunkcionális elvárásokat a Diszfunkcionális Attitűd Skála (DAS) segítségével térképeztük fel. A kérdőív a külső elismerés, a szeretettség, a teljesítmény igényét, a perfekcionizmust, az omnipotencia- és külsőkontroll-igényt, valamint a jogosnak érzett, de irreális elvárásokat méri 9 kérdés alapján, hogy az adott jelenség a válaszadóra nézve mennyire jellemző $[11,12]$.

A hangulatzavar kimutatásához a Beck Depresszió Kérdőív rövidített változatát alkalmaztuk. A skála értékelésekor a hozzárendelt pontszámok segítségével elkülöníthetünk súlyos/közepesen súlyos/enyhe depressziót, illetve depresszió nélküli állapotot $[13,14]$.

Az Erőfeszítés-Jutalom Egyensúlytalanság Kérdőív a munkahelyi stressz modelljén alapul, amely szerint ha a kifejtett munkahelyi erőfeszítések és az ezért kapott jutalmak aránya nem megfelelő, az ebből adódó feszültség egészségromlást okozhat. 15 kérdésben elemzi, hogy a válaszadókra az állítások mennyire jellemzőek egy négy-, illetve ötfokozatú skálán $[15,16]$.

A Társas Támogatás Kérdőív méri, hogy nehéz élethelyzetekben az egyének milyen mértékben és kitől számíthatnak társas támogatásra, illetve a társas kapcsolati háló szereplőit, a kapcsolatok kiterjedtségét, erősségét és a társas támogatásnak a kiégésben betöltött szerepét analizálja $[17,18]$.

Az adatok a leíró statisztika eszköztárával, T-próbával, lineáris regresszióval, korrelációszámítással, varianciaanalízissel, faktoranalízissel kerültek elemzésre.

\section{Eredmények}

Összesen 320 kérdőívet küldtünk ki, ebből 300 fó $(93,8 \%)$ töltötte ki a kérdőívet: 106 férfi, 194 nő. A munkavállalók 3 különböző munkahelyen dolgoztak, 120 (40\%), 105 (35\%) és 75 fó (25\%) megoszlásban.

Demográfiai adatok: A munkavállalók döntően a fiatal/középkorú korcsoporthoz tartoznak, a 26-45 év közöttiek aránya $52,2 \%$. A házasságban élők aránya $35,5 \%$, az egyedülállóké 24,1\% és a kapcsolatban élőké 29,2\%.
A gyermekkel még nem rendelkező munkatársak aránya $38,6 \%$. A válaszadók 22,6\%-a vállal másodállást. A demográfiai adatokat az 1. táblázat tartalmazza.

Burnout: Az átlagos kiégési pontszám 53,9 (SD = $18,7)$ volt, melyből 105 fó $(35,1 \%)$ alacsony, 182 fó $(60,6 \%)$ közepes és 13 fó (4,3\%) súlyos kiégéssel érintett (2. táblázat).

Válaszadóink körében az érzelmi kimerülés alskálájának átlagpontszáma 20,0 (SD = 8,4), a deperszonalizációs alskáláé 12,9 (SD = 4,9), míg a teljesítményvesztési alskála átlagpontszáma 21,1 $(\mathrm{SD}=8,0)$ pont volt. Az érzelmi kimerülés alacsony övezetébe a válaszadók 52,9\%-a, a közepes övezetébe 43,5\%-uk, míg magas övezetébe 3,6\%-uk tartozott.

A deperszonalizáció esetében a minta $32,2 \%$-a tartozott az alacsony övezetbe, 58,8\%-a a közepes, míg 9,0\%-a a magas tartományba.

1. táblázat |A vizsgálatban részt vevő dolgozók demográfiai adatai

\begin{tabular}{|c|c|}
\hline Nem & $(\%)$ \\
\hline Nő & 64,7 \\
\hline Férfi & 35,3 \\
\hline Életkor & $(\%)$ \\
\hline 18-25 év & 15,6 \\
\hline 26-35 év & 26,4 \\
\hline $36-45$ év & 25,8 \\
\hline $46-55$ év & 18,1 \\
\hline 56-62 év & 8,7 \\
\hline 62 év felett & 5,4 \\
\hline Családi állapot & $(\%)$ \\
\hline Hajadon/nótlen & 24,1 \\
\hline (Élettársi) kapcsolatban él & 29,2 \\
\hline Házas & 35,5 \\
\hline Elvált/özvegy & 11,2 \\
\hline Gyermekek száma & $(\%)$ \\
\hline Nincs & 38,6 \\
\hline 1 gyermek & 29,9 \\
\hline 2 gyermek & 21,4 \\
\hline 3 vagy több gyermek & 10,1 \\
\hline Munkában töltött évek száma & $(\%)$ \\
\hline 1-12 hónap & 11,3 \\
\hline 2-5 év & 22,0 \\
\hline 6-10 év & 21,7 \\
\hline 11-20 év & 24,3 \\
\hline 21-30 év & 12,7 \\
\hline 31-40 év & 6,1 \\
\hline Több mint 40 év & 1,9 \\
\hline Munkahelyek száma & $(\%)$ \\
\hline Ez a föállása & 77,4 \\
\hline Más munkahelyen is dolgozik & 22,6 \\
\hline
\end{tabular}


A teljesitménycsökkenési alskálát végigtekintve megállapíthatjuk, hogy a válaszadók 34,3\%-a az alacsony övezetbe, $56,3 \%$-a a közepes és 3,4\%-a a magas övezetbe tartozott.

A pályakezdő fiatalok (25 év alattiak), valamint a 62 év felettiek érintettek a legnagyobb arányban súlyos kiégéssel (az átlaghoz képest 2 százalékponttal magasabb arányban: a pályakezdók 7,3\%-ban, illetve a nyugdíj előtt állók 6,6\%-ban; p<0,05). A 11-20 éve, valamint több mint 40 éve a pályán dolgozóknál súlyos fokú kiégést nem tapasztaltunk (vagyis a munkában töltött évek elején magasabb arányú, majd csökkenő tendencia érvényesül, illetve nyugdíjba vonulás előtt magasabb értékeket figyelhetünk meg) (2. táblázat).
A kiégés demográfiai adatait végigtekintve elmondható, hogy az emocionális kimerülés közepes és magas komponense szignifikánsan gyakrabban fordul elő a legalább 2 gyermeket nevelők (az átlaghoz képest 1,7-szeres mértékben $[\mathrm{p}=0,009])$ és a pályakezdők (69,7\% vs. 52,0\%; $\mathrm{p}=0,011)$ körében. Az életkor is hatással van az érzelmi kimerültségre: a 25 év alattiak (10,9\% vs. 3,6\%; p = $0,019)$ és a nyugdíjkorhatár előtt állók (5,9\% vs. 3,6\%; $\mathrm{p}=0,013)$ körében szignifikánsan magasabb a súlyos kiégés (2. táblázat).

A deperszonalizáció közepes és magas aránya a nők körében gyakrabban fordul elő (76,3\% vs. 55,7\%; p = $0,006)$. A rizikófaktor ebben a dimenzióban a sokgyermekes családi háttér: a legalább három gyermeket válla-

2. táblázat |A kiégés, a depresszió és a diszfunkcionális attidűdök előfordulása a vizsgált populációban

\begin{tabular}{|c|c|c|c|c|c|c|c|c|}
\hline \multirow[t]{2}{*}{ A válaszadók adatai } & \multicolumn{3}{|c|}{ Kiégés } & \multicolumn{3}{|c|}{ Depresszió } & \multicolumn{2}{|c|}{ DAS } \\
\hline & Alacsony & Közepes & Magas & Nem/enyhe & Közepes & Súlyos & Nem/enyhe & Közepes \\
\hline Nem & $\%$ & $\%$ & $\%$ & $\%$ & $\%$ & $\%$ & $\%$ & $\%$ \\
\hline Nő & 33,6 & 61,2 & 5,2 & 57,1 & 31,9 & 11,0 & 22,2 & 65,0 \\
\hline Férfi & 36,7 & 60,0 & 3,3 & 68,8 & 23,9 & 7,3 & 26,8 & 61,9 \\
\hline \multicolumn{9}{|l|}{ Életkor } \\
\hline 18-25 év & 31,7 & 61,0 & 7,3 & 27,7 & 42,6 & 29,7 & 21,8 & 56,5 \\
\hline 26-35 év & 32,8 & 64,1 & 3,1 & 27,3 & 46,7 & 26,0 & 16,2 & 71,6 \\
\hline 36-45 év & 47,7 & 49,2 & 3,1 & 33,4 & 58,3 & 8,3 & 35,5 & 60,5 \\
\hline 46-55 év & 29,8 & 66,0 & 4,2 & 20,8 & 50,9 & 28,3 & 17,0 & 69,8 \\
\hline 56-62 év & 30,0 & 65,0 & 5,0 & 28,0 & 52,0 & 20,0 & 40,0 & 44,0 \\
\hline 62 év felett & 26,7 & 66,7 & 6,6 & 6,2 & 62,8 & 25,0 & 12,5 & 75,0 \\
\hline \multicolumn{9}{|l|}{ Családi állapot } \\
\hline Hajadon/nőtlen & 39,3 & 55,7 & 4,9 & 30,0 & 44,3 & 25,7 & 12,8 & 78,6 \\
\hline (Élettársi) kapcsolatban él & 41,8 & 56,7 & 1,5 & 30,0 & 52,5 & 17,5 & 17,7 & 77,5 \\
\hline Házas & 28,3 & 65,2 & 6,5 & 24,0 & 54,8 & 21,2 & 18,1 & 70,9 \\
\hline Elvált/özvegy & 37,9 & 58,6 & 3,4 & 21,9 & 53,1 & 25,0 & 2,8 & 95,8 \\
\hline \multicolumn{9}{|l|}{ Gyermekek száma } \\
\hline Nincs & 44,2 & 51,6 & 4,2 & 31,9 & 51,3 & 16,8 & 25,5 & 60,9 \\
\hline 1 gyermek & 32,9 & 65,7 & 1,4 & 22,6 & 46,4 & 31,0 & 21,8 & 65,6 \\
\hline 2 gyermek & 19,0 & 72,4 & 8,6 & 22,2 & 54,0 & 23,8 & 14,3 & 74,6 \\
\hline 3 vagy több gyermek & 38,5 & 57,7 & 3,8 & 27,6 & 58,6 & 13,8 & 48,3 & 44,8 \\
\hline \multicolumn{9}{|l|}{ Munkában töltött évek száma } \\
\hline 1-12 hónap & 22,6 & 71,0 & 6,5 & 11,8 & 32,4 & 55,8 & 8,8 & 67,6 \\
\hline 2-5 év & 33,9 & 60,7 & 5,4 & 21,3 & 54,5 & 24,2 & 22,2 & 65,1 \\
\hline 6-10 év & 35,8 & 58,5 & 5,7 & 34,4 & 50,0 & 15,6 & 19,0 & 66,7 \\
\hline 11-20 év & 47,5 & 52,5 & 0,0 & 40,3 & 52,2 & 7,5 & 38,6 & 58,6 \\
\hline 21-30 év & 25,0 & 68,8 & 6,3 & 21,6 & 54,1 & 24,3 & 26,3 & 60,5 \\
\hline $31-40$ év & 28,6 & 64,3 & 7,1 & 11,8 & 58,8 & 29,4 & 23,5 & 64,7 \\
\hline Több mint 40 év & 40,0 & 60,0 & 0,0 & 0,0 & 80,0 & 20,0 & 0,0 & 80,0 \\
\hline \multicolumn{9}{|l|}{ Munkahelyek száma } \\
\hline Ez a fóállása & 38,4 & 58,6 & 3,0 & 27,0 & 52,7 & 20,4 & 25,4 & 62,9 \\
\hline Más munkahelyen is dolgozik & 22,2 & 68,5 & 9,3 & 25,4 & 46,0 & 28,6 & 18,8 & 70,3 \\
\hline
\end{tabular}

DAS = Diszfukcionális Attitűd Skála 
lóknál (14,3\% vs. 9,6\% a kevesebb gyermeket vállalóknál; $\mathrm{p}=0,046)$ (2. táblázat).

A teljesitményvesztés közepes és magas aránya a 18-35 év közöttieket érinti nagyobb mértékben (70,9\% vs. $54,2 \%$ a 36-55 év közötti korcsoportban; $\mathrm{p}=0,035)$. A nyugdíjba vonulás előtt álló munkavállalók között csaknem kétszeres arányban (12,5\%-ban) figyelhető meg magas kiégés ebben a dimenzióban a 36-55 év közöttiekhez viszonyítva $(5,7 \%)$ (2. táblázat).

\section{Kiégés és depresszió, diszfunkcionális attitüdök}

A válaszadók 13,0\%-a nem, 48,3\%-a enyhén, 29,0\%-a közepes fokban depressziós, míg súlyos fokú hangulatzavarban 9,7\% szenved. A depresszió szignifikáns rizikótényezője a pályán eltöltött évek száma: a több mint 40 éve a szociális szférában dolgozók átlagosan 80,0\%-a az enyhe, illetve a közepesen súlyos depresszió csoportjába tartozik ( $\mathrm{p}=0,025)$, a több mint 30 éve a pályán tevékenykedők 88,8\%-a súlyos depresszióval érintett. A 62 év feletti munkavállalók az átlaghoz képest 2,6-szoros mértékben (38,1\%-ban) érintettek súlyos depresszióval. A depresszió súlyossága és a kiégés között szignifikáns kapcsolat számszerüsíthető. Míg az enyhe fokú depresszióval küzdők körében súlyos kiégés nem figyelhető meg, a súlyos depresszióban szenvedők 10,9\%-a súlyosan kiégett $(\mathrm{p}<0,001)$. Az enyhe fokú kiégésben szenvedők 40,9\%-a enyhe fokú hangulatzavarral is küzd, míg a súlyos kiégéssel érintettek 58,3\%-a súlyosan depressziós $(\mathrm{p}<0,001)$ (2. táblázat). Megemlítendő, hogy a diszfunkcionális attitüdök és a kiégés között pozitív kapcsolat igazolódott (korrelációs együttható $=0,316$; $\mathrm{p}<0,001)$.

\section{Kiégés és társas támogatás, megküzdési stratégiák}

Általában boldognak, kiegyensúlyozottnak a válaszadók 64,5\%-a érzi a magánéletét. A válaszadók 74,6\%-a jó társas kapcsolatot ápol munkatársaival és munkahelyi vezetőjével, 35,1\%-uk számíthat kollégái segítségére a napi munkavégzés során, továbbá 22,5\%-uk érez szakmai megbecsülést. A rendszeres edukációban részt vevő́k aránya 47,2\%. A kérdőívet kitöltők 32,2\%-a érzi biztosnak a munkahelyét, 18,2\%-a kilátástalannak tartja jövőjét. A kiégéssel érintett szociális munkások 64,8\%-a pályát módosítana, a kiégéssel nem érintettek $61,4 \%$-a vélekedik így. A javadalmazást illetően a kérdóívet kitöltők 78,6\%-a vélekedik kedvezőtlenül. A kiégés és a szakmai megbecsülés szintje $(\mathrm{p}<0,001)$, a jövedelem $(\mathrm{p}<0,001)$, valamint a kollegiális támogatás $(\mathrm{p}=0,016)$ között pozitív kapcsolat igazolódott. A teljesítménycsökkenésre és a deperszonalizációra a leginkább a jövedelmi helyzet megítélése $(p<0,001)$ és a szakmai megbecsülés mértéke $(\mathrm{p}<0,001)$ van hatással.
A multivariációs analizis során a nói nem (OR: 5,857 ), az életkor (OR: 4,126), a munkában eltöltött évek (OR: 2,721), a sokgyermekes család (OR: 2,861) és a társas támogatás hiánya (OR: 2,81) bizonyultak a kiégés független rizikótényezőinek $(\mathrm{p}<0,05$ minden esetben).

\section{Megbeszélés}

Munkánk az első, mely a szociális munkások kiégésének komplex hátterével foglalkozik hazánkban. Korábban hasonló cikk irodalmi kutatásunk és tudomásunk alapján nem született, csupán egy 2016-os, magyar nyelvú erdélyi felmérés eredményei állnak rendelkezésre, de ott öszszesen 34 idősgondozó és szociális munkás vizsgálata történt [2].

Eredményeink alapján a szociális munkások jelentős része, mintegy $60 \%$-a közepes fokú, míg mintegy 5\%-a súlyos fokú kiégésben szenved. Különösen magas a deperszonalizáció aránya: a súlyos fokú deperszonalizáció akár a dolgozók 10\%-át érintheti, ami egyértelmúen csökkenő elkötelezettséget jelent a gondozottak és az általában vett más emberek iránt [2]. A fent leírt adatok nemzetközi összevetésben is kiemelkednek: a szociális munkások mintegy 15\%-a szenved döntően enyhe fokú kiégésben, közepes vagy súlyos fokú kiégés jóval alacsonyabb mértékben fordul elő mintánk adataihoz képest az eddig megjelent publikációk alapján $[8,19]$.

Hazai adatok alapján az egészségügyben dolgozók mintegy fele valamilyen fokú kiégésben szenved, azonban a veszélyeztetett szakmák sorában az elsők között szerepelnek a szociális tevékenységgel kapcsolatos munkakörök is [20]. A talált kiégési arány a kapott magyar eredményeknél is jóval magasabb a vizsgált populációban $[2-5]$.

Megemlítenő, hogy bár a gyermekvédelemben dolgozó szociális munkások kiégési aránya magasabb az átlaghoz képest a rendelkezésre álló szakirodalmi adatok alapján, vizsgálatunkban nemzetközi összehasonlításban is kiemelkedő a kiégés és a súlyos fokú depresszió aránya. A fent említett erdélyi cikk is jóval alacsonyabb fokú kiégést talált a vizsgált dolgozók között, magas fokú kiégés nem is volt kimutatható [2].

Némiképpen meglepő módon a pályakezdő fiatalok (25 év alattiak), valamint a 62 év felettiek érintettek a legnagyobb arányban súlyos kiégéssel (az átlaghoz képest 2 százalékponttal magasabb arányban: a pályakezdők 7,3\%-ban, illetve a nyugdíj előtt állók 6,6\%-ban). A fơiskolákon, egyetemeken tanuló diákok körében egyre magasabb a kiégés aránya, mint ezt a közelmúltban publikált összefoglaló analízisek is alátámasztják [21]. Azaz a kiégés nemcsak a munkahelyen eltöltött évek során, hanem már a tanulmányok során is kialakulhat, és ez a későbbi munkavégzésre is negatív hatással lehet, mint eredményeink is alátámaszthatják [18].

Az életkor mellett a családi állapot (3 gyermeket vs. kevesebb gyermeket vállalók), illetve a női nem bizo- 
nyult a kiégés rizikótényezőjének mind uni-, mind multivariációs analízis során. A pályakezdés és az ezzel járó relatív tapasztalatlanság, a rutin hiánya és ennek összefüggése a munkahelyi kiégéssel már korábban is leírásra került [22]. Noha a család védôszerepe már igazolódott, eredményeink alapján a sokgyermekes családokban élók mégis nagyobb kiégési kockázatnak vannak kitéve társaikhoz képest [23]. Ennek magyarázata az lehet, hogy a vizsgált munkavállalók túlnyomó többsége nő, akikre a munka mellett még a gyermeknevelés döntő része is hárul, így hamarabb kimerülnek érzelmileg [24].

Tanulmányunk szoros összefüggést igazolt a kiégés és a diszfunkcionális attitúdök között. A DAS azokat a - nem feltétlenül kóros -, jelen esetben munkahelyi beállítottságokat méri, amelyek hajlamosak boldogtalanná tenni az embert, stresszt okozni, ami bénítóvá is válhat, erôs szorongáshoz vezethet, ezáltal kiégést okozva. Vagyis vannak bizonyos viselkedésminták (perfekcionalizmus stb.), melyek fennállása magasabb kiégési kockázattal jár.

Kiemelendő, hogy a dolgozóknak csupán mintegy a kétharmada érzi kiegyensúlyozottnak a magánéletét: ez is szerepet játszhat a kiégésben, hisz a biztos családi háttér protektív szerepe ismert [23]. Túlnyomó többségük jó kapcsolatot ápol a munkahelyén, de csupán harmaduk számíthat kollégái segítségére, szakmai megbecsülést pedig még kevesebben éreznek. Döntő többségük elégedetlen a javadalmazásával, és mintegy kétharmaduk pályát változtatna. A kiégés és a szakmai megbecsülés szintje, a jövedelem, valamint a kollegiális támogatás között szignifikáns összefüggés igazolódott. A társas támogatás (illetve annak hiánya) multivariációs analízisben a kiégés független rizikótényezőjének bizonyult. A munkahelyi légkör, a munkahelyi támogatottság hiánya a kiégés prediktív faktorának bizonyult korábbi tanulmányok alapján egészségügyi munkakörökben, de ennek meghatározó szerepe korábban nem került leírásra szociális munkások esetében $[21,25,26]$.

Noha ez néha a szakirodalomban sem egyértelmü, közelmúltbéli vizsgálatok alapján a szorongás és a depresszió a kiégéstől egyértelmúen különböző kórképek [26-28]. A kiégés hosszabb távon pszichiátriai komplikációkhoz vezet (szorongás, alvászavar, depresszió stb.), továbbá szoros összefüggést mutat a kedvezótlen cardiovascularis kimenetellel is [3, 21, 29]. A depresszió megelǒzése és kezelése kiemelkedően fontos; az Egészségügyi Világszervezet (WHO) szerint az állandó teljesítménykényszer és a munkahelyi túlzott megterhelés miatt 2030-ra a depresszió lesz a vezető betegség, és az ebból adódó halálozás (suicidum) is a vezetố halálokok közé fog tartozni [30]. A téma fontosságára hívja fel a figyelmet a súlyos fokú depresszió előfordulásának magas aránya a vizsgált csoportban.

Megemlítendő, hogy Magyarországon évente mintegy 440 milliárd forintra becsülik a munkahelyi stressz okozta költségeket, amelyek az Európai Unióban a 136 milliárd eurót is elérhetik [31-34].
Összegezve, vizsgálatunk az első, mely a kiégés komplex hátterét próbálta felderíteni szociális munkások körében. Eredményeink alapján a szociális munkások jelentős része közepes fokú kiégésben, 5\%-uk súlyos fokú kiégésben szenved, jelentős részük pedig súlyos fokú depresszióban is. A kiégésnek vannak befolyásolható (munkahelyi attitúdök, társas támogatás) és nem befolyásolható (életkor, nem, család) tényezői, melyeket az esetleges prevenciós, illetve intervenciós beavatkozások során figyelembe kell venni. Hangsúlyoznunk kell a megfelelő munkahelyi atmoszféra kialakításának fontosságát, mely egyértelmúen prevenciós szereppel bír.

Meg kell említeni, hogy tanulmányunk korlátokkal is bír. Először is a minta nem reprezentatív, így következtetéseink sem minden szociális munkásra, sem pedig a szociális szférára általánosságban nem vonatkoznak, csupán a vizsgált populációra. Az sem ismert, hogy a vizsgált szociális munkások hány százaléka dolgozik ugyanazon a munkahelyen (intézményben), és ez hogyan módosítja az eredmények értékelését - ezek feltehetőleg befolyásolják következtetéseinket, ugyanis a munkahelyi légkör, a munkahelyi támogatottság hiánya a kiégés legjelentô" sebb prediktorai közé sorolhatók.

Anyagi támogatás: A szerzők anyagi támogatásban nem részesültek.

Szerzői munkamegosztás: A szerzők egyenlő mértékben vettek részt az anyaggyújtésben, az adatok feldolgozásában és a kézirat megírásában. A cikk végleges változatát valamennyi szerző elolvasta és jóváhagyta.

Érdekeltségek: A szerző́knek a kézirattal kapcsolatban nincsenek érdekeltségeik.

\section{Köszönetnyilvánítás}

A szerzők köszönik az Állami Gondoskodásban Élő és Veszélyeztetett Fiatalok Támogatásáért Alapítvány segítségét, mely nélkül a jelen cikk meg sem születhetett volna.

\section{Irodalom}

[1] West CP, Dyrbye LN, Erwin PJ, et al. Interventions to prevent and reduce physician burnout: a systematic review and metaanalysis. Lancet 2016; 388: 2272-2281.

[2] Kiss CsB, László E. Burnout research in the case of elderly caregivers and social workers. [A kiégés vizsgálata az idősgondozók és szociális munkások körében.] Erdélyi Társadalom 2016; 14: 49-64. [Hungarian]

[3] Irinyi T, Németh A, Lampek K. The relationship of mental health status, violent acts and workplace conflicts among health care providers. [Az egészségügyi szakdolgozók kiégettségének összefüggése az egészségügyi ellátás során kialakuló agressziós cselekmények gyakoriságával és a munkahelyi konfliktussal.] Mentálhig Pszichoszom. 2018; 19: 205-220. [Hungarian]

[4] Czeglédi E, Tandari-Kovács M. Characteristics and prevention of burnout syndrome among nurses. [A kiégés előfordulása és 
megelőzési lehetőségei ápolók körében.] Orv Hetil. 2019; 160: 12-19. [Hungarian]

[5] Adam Sz, Mohos A, Kalabay L, et al. Potential correlates of burnout among general practitioners and residents in Hungary: the significant role of gender, age, dependant care and experience. BMC Fam Pract. 2018; 19: 193.

[6] Salvagioni DA, Melanda FN, Mesas AE, et al. Physical, psychological and occupational consequences of job burnout: a systematic review of prospective studies. PLoS ONE 2017; 12: e0185781.

[7] Takeda F, Ibaraki N, Yokoyama E, et al. The relationship of job type to burnout in social workers at social welfare offices. J Occup Health 2005; 47: 119-125.

[8] Wilson F. Identifying, preventing, and addressing job burnout and vicarious burnout for social work professionals. J Evid Inf Soc Work 2016; 13: 479-483.

[9] Maslach C, Jackson SE. The measurement of experienced burnout. J Occup Behav. 1981; 2: 99-113.

[10] Ádám Sz, Mészáros V. Psychometric properties and health correlates of the Hungarian Version of the Maslach Burnout Inventory - Human Services Survey (MBI-HSS) among physicians. [A humán szolgáltató szektorban dolgozók kiégésének mérésére szolgáló Maslach Kiégés Leltár magyar változatának pszichometriai jellemzói és egészségügyi korrelátumai orvosok körében.] Mentálhig Pszichoszom. 2012; 13: 127-144. [Hungarian]

[11] de Graaf LE, Roelofs J, Huibers MJ. Measuring dysfunctional attitudes in the general population: the Dysfunctional Attitude Scale (form A) Revised. Cognit Ther Res. 2009; 33: 345-355.

[12] Kopp M. (ed.) Medical psychology. [Orvosi pszichológia.] Semmelweis Orvostudományi Egyetem, Magatartástudományi Intézet, Budapest, 1994. [Hungarian]

[13] Beck AT, Ward CH, Mendelson M, et al. An inventory for measuring depression. Arch Gen Psychiatry 1961; 4: 561-571.

[14] Rózsa S, Szádóczky E, Füredi J. Characteristics of the abbreviated version of the Beck Depression Questionnaire in a Hungarian sample. [A Beck Depresszió Kérdőív rövidített változatának jellemzői hazai mintán.] Psychiatr Hung. 2001; 16: 384-402. [Hungarian]

[15] Siegrist J. Adverse health effects of high-effort/low-reward conditions. J Occup Health Psychol. 1996; 1: 27-41.

[16] Salavecz Gy, Neculai K, Rózsa S, et al. Reliability and validity of the Hungarian version of the Effort-Reward Imbalance Questionnaire. [Az Erőfeszítés-Jutalom Egyensúlytalanság Kérdőív magyar változatának megbízhatósága és érvényessége.] Mentálhig Pszichoszom. 2006; 7: 231-246. [Hungarian]

[17] Caldwell RA, Pearson JL, Chin RJ. Stress-moderating effects: Social support in the context of gender and locus of control. Person Soc Psychol Bull. 1987; 13: 5-17.

[18] Kopp M, Skrabski Á. (eds.) Hungarian state of mind. [Magyar lelkiállapot.] Végeken Alapítvány, Budapest, 1992. [Hungarian]

[19] Evans S, Huxley P, Gately C, et al. Mental health, burnout and job satisfaction among mental health social workers in England and Wales. Br J Psychiatry 2006; 188: 75-80.

[20] Kegye A, Zana A, Révay E, et al. The real cost of caring for seriously ill patients - compassion fatigue or satisfaction. [A súlyos betegek ellátásának igazi ára - az együttérzésből fakadó fáradtság vagy elégedettség.] LAM 2015; 25: 129-136. [Hungarian]

[21] Ishak W, Nikravesh R, Lederer S, et al. Burnout in medical students: a systematic review. Clin Teach. 2013; 10: 242-245.
[22] Kirkham R, Rumbold A, Hoon E, et al. Emotional labour and aboriginal maternal infant care workers: the invisible load. Women Birth 2018; 31: 110-116.

[23] Bourassa DB. Compassion fatigue and the adult protective services social worker. J Gerontol Soc Work 2009; 52: 215-229.

[24] Huang SL, Li RH, Fang SY, et al. Work hours and difficulty in leaving work on time in relation to work-to-family conflict and burnout among female workers in Taiwan. Int J Environ Res Public Health 2020; 17: 605.

[25] Kovács M, Kovács E, Hegedús $\mathrm{K}$. The relationship between emotion work and burnout. A comparative study in various groups of health care workers. [Az érzelmi munka és a kiégés összefüggései egészségügyi dolgozók különböző csoportjaiban.] Mentálhig Pszichoszom. 2012; 13: 219-241. [Hungarian]

[26] Mihálka M. About burnout - overview of Hungarian and international research. [A kiégésről - nemzetközi és hazai kutatási kitekintés.] Acta Sana 2015; 10: 7-18. [Hungarian]

[27] Adam Sz, Nistor A, Nistor K, et al. Facilitating the diagnosis of depression and burnout by identifying demographic and workrelated risk and protective factors among nurses. [A kiégés és a depresszió diagnosztizálásának elősegítése demográfiai és munkahelyi védő- és kockázati tényezőik feltárásával egészségügyi szakdolgozók körében.] Orv Hetil. 2015; 156: 1288-1297. [Hungarian]

[28] Kim H, Ji J, Kao D. Burnout and physical health among social workers: a three-year longitudinal study. Soc Work 2011; 56: 258-268.

[29] Koutsimani P, Montgomery A, Georganta K. The relationship between burnout, depression, and anxiety: a systematic review and meta-analysis. Front Psychol. 2019; 10: 284.

[30] Malhi GS, Mann JJ. Depression. Lancet 2018; 392: 2299-2312.

[31] European Agency for Safety and Health at Work (EU-OSHA). Calculating the cost of work-related stress and psychosocial risks. European Risk Observatory. Literature Review. Bilbao, 2014. Available from: https://osha.europa.eu/en/publications/literature_reviews/calculating-the-cost-of-work-related-stress-andpsychosocial-risks.

[32] Marek E, Kalmár R, Faubl N, et al. Prejudices and their healthcare implications. Lessons learnt from a national survey. [Elöítéletek és hatásaik az egészségügyi ellátásban. Egy felmérés tanulságai.] Orv Hetil. 2020; 161: 789-796. [Hungarian]

[33] Sipos D, Varga V, Pandur AA, et al. Burnout level among radiology department workers in Hungary. [Radiológiai osztályon dolgozó szakdolgozók kiégési szintje Magyarországon.] Orv Hetil. 2019; 160: 1070-1077. [Hungarian]

[34] Stankovic M, Töreki A, Lázár G, et al. Investigation of the burnout syndrome among the employees of the Department of Surgery at the University of Szeged and comparison with the results of the Department of Emergency Medicine. [A kiégésszindróma vizsgálata a Szegedi Tudományegyetem Sebészeti Klinikájának dolgozói körében és összehasonlítása a Sürgősségi Betegellátó Önálló Osztályon kapott eredményekkel.] Orv Hetil. 2019; 160: 784-791. [Hungarian]

(Fehér Gergely dr., Pécs, Nyár u. 8., 7624 e-mail: feher.gergely@pte.hu

A cikk a Creative Commons Attribution 4.0 International License (https://creativecommons.org/licenses/by/4.0/) feltételei szerint publikált Open Access közlemény, melynek szellemében a cikk bármilyen médiumban szabadon felhasználható, megosztható és újraközölhető, feltéve, hogy az eredeti szerző és a közlés helye, illetve a CC License linkje és az esetlegesen végrehajtott módosítások feltüntetésre kerülnek. (SID_1) 